\title{
Sources of Funding and Financing Opportunities for Agricultural Business
}

\author{
Ch. Assistant Professor Dr. Tsvetelina Kabakchieva \\ D. A. Tsenov Academy of Economics - city of Svishtov, Svishtov, Bulgaria \\ ts.kabakchieva@uni-svishtov.bg
}

\begin{abstract}
The purpose of the present exploratory case study is to justify and determine the innovative lease as a possible alternative to effectively solve and overcome the investing problems affecting the innovative development of agribusinesses. The actual relevance of lease transactions is related on the one hand to the dynamic structural changes and transformations in a number of industries along with the obsolescence management of equipment and technologies, and on the other hand - to the high demands for obtaining financial instruments based long-term loans, both at the domestic and international levels.
\end{abstract}

Keywords: agribusiness, finance lease, lease transactions

JEL Code: $G 24,016,013, Q 13, Q 14$

DOI: https://doi.org/10.36997/IJUSV-ESS/2020.9.3.72

\section{Introduction}

The goal of this scientific research is intended to clarify the economic nature of innovative leases as an alternative economic model designed to ensure sources of financing in the agricultural sector. Investing activity constitutes one of the mechanisms for engaging and enabling agribusiness technological innovation and for boosting its prospects for development. In the context of the global financial crisis, economic agents representing this specific sector must look for new, non-traditional financing sources with respect to their activities. The use of a leasing becomes one of the methods to effectively solve the problems of investing in the innovative agribusiness development. The actual relevance of lease transactions is related on the one hand to the dynamic structural changes and transformations held in a number of industries along with the obsolescence management of equipment and technologies, and on the other hand - to the high demands for obtaining financial instruments-based long-term loans, both at the domestic and international levels .

\section{Agribusiness-related investment solutions}

Financial investments represent an integral part of managing an organization. Effective management of financial resources is a prerequisite for promoting the economic agents ' prosperity; a way to increase the value of the specific business and improve and boost profit levels. The investment choice and investment decision-making processes are of utmost importance for ensuring rationality with regard to the investment activity - and those processes require the involvement of resources, knowledge and skills across various areas of financial analysis` fields of expertise. Therefore, the agribusiness economic development is a dependent variable based on the success of the investment decisions strategy. The main investment challenges in the agribusiness industry are related to following uncertainties agents are looking for before investing: "In what manner and where to invest?; Is actually investing necessary or required at this current stage?; What is the most efficient capital investment option?; Will the investment be successful and profitable?". The effective financial management of a company would provide a convenient response to these and any further questions in order to subsequently proceed with an appropriate analysis to make the right investment decisions that will give rise not only to the increase of the value of business, but also would set in motion the agribusiness ' prosperity and development. In order for management to take moderate risk, which will ultimately lead to an increase in the company's revenue and profit margins, the basic principles of financial management must be well known. The effective agricultural entities' development depends on the proper management of their investments, as they are the key prerequisite for increasing the company's revenue, for improving cash inflows and, as a result of the foregoing, become drivers to contribute to the company growth. Investing activities 
constitute specific source for increasing income, they have a central role with respect to the business organizations' activities, and their absence would prevent economic entities from carrying out their normal course of business.

To put it another way, investing is a type of financial activity related to the management of the assets of business units. The effective management of funds provided by the agricultural companies represents proof of the profitability and prospects of the business itself. The drivers triggering large capital movements, which lay the foundation of the existence and going concern model of public and private companies, are directly dependent upon the appropriate use of investment as a universal mechanism for redirecting savings to activities that have a rate of return greater than or equal to the market interest rate. Business or economic investments are applied in situations where the funds are used to acquire business assets that will bring in such income that they can compensate for the risk inherent in the economic endeavor. Profit motive is the main driver behind any economic transaction, which constitutes the basis of the relevant initiated endeavor. All agricultural companies that are engaged in a particular activity take steps to invest in various activities. Investing is a process that has a special economic significance, provides a return, and obeys the logical order of operations. The following features are of crucial importance:

$>$ The economic importance of investment - the efficient functioning, development of the economy and its overall growth are determined by capital and funds to meet the need for funding conducted both by the state and the individuals. The fact that individuals are net bidders and the State and companies are net capital seekers is essential for investment.

$>$ Investment income - could be obtained in two forms: current income or increased value.

$>\quad$ Marginal investment conditions - the economic agent must analyze its activities before investing, as well as become acquainted with its going concern status. This is necessary because investments cannot be considered as an alternative to the going concern principle, but only as a way to use cash income to meet the future needs of the business organization.

$>$ Establishment of investment goals - the process of setting investment goals is determined by the definition of the conditions and the precise specification of the financial goals. This establishment requires a specific allocation of time, extent and risk associated with the expected return.

$>\quad$ Valuation of investment vehicles - the valuation includes measurement of both potential returns and risk relevant to each investment vehicle.

$>$ Choosing the right investment option - this is the most important stage because it can determine the course of action. This is also the stage that can significantly affect the investment success, when the goals are realized as planned. In this situation, a good investment may be the one that avoids risk and taxes, and not just the one that simply maximizes returns.

Based on the "investment transaction" criteria, I will consider the grouping of investments in terms of their classification, namely:

* Consumer investment - if the transformation or acquisition of an asset does not lead to the achievement of income or profit, then these investments are aimed at ensuring the economic existence of the economic agents.

* Economic investments - unlike consumer investments, they are intended for generating profit. The transformation of assets is carried out in order to ensure availability of material conditions for the manufacture of products.

* Financial investments are directly related to economic investments.

Hence the following features could be outlined, namely:

- The investment of a financial asset constitutes financing for the seller of the investment.

- A fictitious asset is one in which financial investments are made.

- The investment asset arises on the basis of the need for financing and has a production nature. 
Capital budgeting is a process that involves planning and controlling of the income and expenses associated with investments in fixed assets. The analysis and synthesis of the comparable characteristics of investment projects in agribusiness is determined by the need for investment opportunities to be assessed. Capital budgeting constitutes a combination of investment and financial decisions. The planning of investment projects and the related financial sources is capital budgeting. By calculating the cost of capital, its return and the risk inherent in that return, the capital budget allocates long-term income and expenses. In regard to all the above facts we can define that "Capital budgeting as a process of generating investment projects, their appraisal and risk indexing and selection of the best projects in terms of maximizing Business value.", (Prodanov, 1999) also and for the formulation of long-term investment projects, which will subsequently bring a long-term return that will exceed the cost of invested capital.

Before the relevant bodies representing agribusiness make the necessary management decisions, a good analysis of the undertaken projects - their advantages and disadvantages - must be performed, as well as all factors of the business environment must be taken into account. Based on this analysis, the management can effectively forecast all the elements that will affect the implementation of the project in order to achieve optimal results and to maximize profits in favor of the company. Without the knowledge, use and application of the principles of budgetary management, all these analyzes will not be possible. Budget management includes a set of tools that help organizations achieve the best possible results in accomplishing their goals and objectives. "The budget management of the company is nothing but a process of predicting with a certain accuracy the future events in the life of the company and creating opportunities to prevent negative trends in financial policy." (Adamov, V., Zakhariev, V., Prodanov, S., 2003)

Any decision to be taken by any agricultural company that is related to certain investment intentions must consider some important factors, namely:

The expected development of the industry - advantages and disadvantages, strengths and threats. All these factors are essential for the successful implementation of investment intentions.

$>$ The amount of cash resources that the company is holder of. Here the answer to the question "Will the organization have enough free funds to carry out its follow-up activities?" should be provided. An analysis must also be made of the ability of the agricultural business to cope with the possible crisis on the market, whether it will be able to resist problems related to the reduction of sales, production, etc.

$>$ Will there be fluctuations in the prices of the offered products and services and if so, will there be a change in the structure of its consumers.

$>$ Determining the risk factors of the agricultural company and taking appropriate measures to eliminate them is a result of the effective implementation of budget management.

Of all the decisions that are made by the management of the company, the only ones that are able to increase the value of the business, and hence the wealth of its owners are investment decisions. Today, the value of the business can be considered as the present value of all expected cash flows.

Cash flows can be divided into two types:

$\checkmark \quad$ Cash flows that result from past investment decisions and are located in the form of assets in existing corporate investment projects.

$\checkmark \quad$ Opportunities for future profitable investment, measured by the present value of the expected cash flows generated by future investment projects.

A prerequisite for minimizing the uncertainty of the project and the overall risk of the project is the process of making investment decisions by the company. This process provides an opportunity for companies to assess the negative aspects of the investment project and to take measures to overcome them. When making an investment decision, it is necessary to perform an analysis of the environment, competition and other factors that could affect the future activities of 
the organization. Financial management must take into account several stages of the investment project to implement an effective decision, as many factors can influence investment decisions, namely:

"Estimation of the expected net cash inflows related to the proposed project."

"Determining the actual value of the expected net cash inflows."

$\sim \quad$ "Estimation of the initial net costs necessary for the implementation of the proposed project."

"Comparison of the actual value of expected net cash inflows relating to these costs." (Adamov, V. et al., 1995)

The fact that future cash flows may be characterized by a degree of uncertainty requires that the risk associated with those cash flows be taken into account. This risk can be defined, on the one hand, as uncertainty about the combination of fixed and variable costs of the company, determining the operational risk, and, on the other hand, as the risk of future sales and sales prices, making up the sales risk. The prospects of an investment project in agribusiness are present when one of the following situations is in place:

$\checkmark \quad$ When the project is implemented so that it can provide the owners of the respective business, cash flows that cover the investment risk assumed by them. In this situation, financial managers can rest assured that this project will provide the organization with an increase in wealth, i.e. increase of the business value and of the share capital.

$\checkmark \quad$ The second situation is related to the presence of a negative project return, ie. when the project provides lower cash flows so that capital owners can be compensated for the risk they take.

$\checkmark \quad$ The third possibility for the prospect of the project represents a scenario where the cash flows are equal to the need to compensate the owners of capital for the risk taken by them.

As this approach makes it possible to outline the benefits and costs of individual projects and on this basis to make rational decisions for their implementation, it ends up being a preferred approach for financial managers. Making an investment decision and making an investment choice are actions that go hand in hand with a number of steps that can lead to the positive implementation of a project. In order to gain a clearer understanding of the individual factors that influence investment decisions, attention must be paid to the budgetary management of investments.

Investments for each agricultural company are a prerequisite for its growth and increase of its wealth. However, without a good financial manager to prepare capital budgets for the investments made by the company, the desired capital increase will not be feasible, respectively the company may even end up in a losing position. It is necessary for specialists to be well acquainted with the specific features of investments, and the most important factor that must be taken into account is their profitability.

\section{Aspects of innovative leasing in agribusiness}

Since 2008, the world has been facing the most serious economic crisis since the Great Depression. The current situation requires quick and adequate solutions to turn the crisis into an opportunity and to restore economic growth. Bulgaria is a full-fledged member of the EU and although the progress in the country's economy is stable, it is not transformed into a better innovation potential. According to the innovation index of Bulgarian enterprises (http://enterpriseeurope-network.bg/2880/indeks-na-inovatsionnata-aktivnost-na-balgarskite-predpriyatiya/) a layer of about one third of the companies has been formed (29-34\%), which innovate every year, with $90 \%$ of them having a non-decreasing innovation budget, and half of them increased it in 2017 compared to 2012. About 7 to $10 \%$ of companies innovate periodically. The Innovation Index of Bulgarian enterprises for 2016 shows that compared to the best developing countries in Central and Eastern Europe - Hungary and the Czech Republic, in Bulgaria enterprises have almost twice lower 
pace of the innovation activity. (Https: // ww.capital.bg/biznes/kompanii/2016/12/07/ 2878703_koi_sa_inovativnite_predpriiatiia_na_2016_g/). The country's innovation system suffers from a shortage of critical mass - research and education infrastructure remain fragmented, leading to a scattering of research potential. Business is weakly involved in the innovation process, and the interaction within the innovation system is inefficient. The latest Community Innovation Survey (https://ec.europa.eu/eurostat/web/microdata/community-innovation-survey) from 2016 demonstrates that the share of innovative companies in Bulgaria is $27.4 \%$ out of all enterprises in Bulgaria in the sector of industry and services and ,based on this criteria, the country holds one of the lowest positions in the EU (See Figure 1).

Bulgaria ranks one of the lowest in the EU in terms of the number of innovative enterprises. This is demonstrated within the results of the Community Innovation Survey, 2016.

The highest share of enterprises engaged in innovation is the one in Germany $(67.0 \%)$, Luxembourg (65.1\%) and Belgium (64.2\%). Ireland, Great Britain and Austria are the following in the list.

Less than a third are the companies active in this field in Romania (12.8\%) and Poland (21.0\%), followed by Latvia (26.5\%), Hungary (26.6\%), Bulgaria (27.4\%) and Estonia (27.8\%).

\section{Дял на иновативните предприятия, \%}

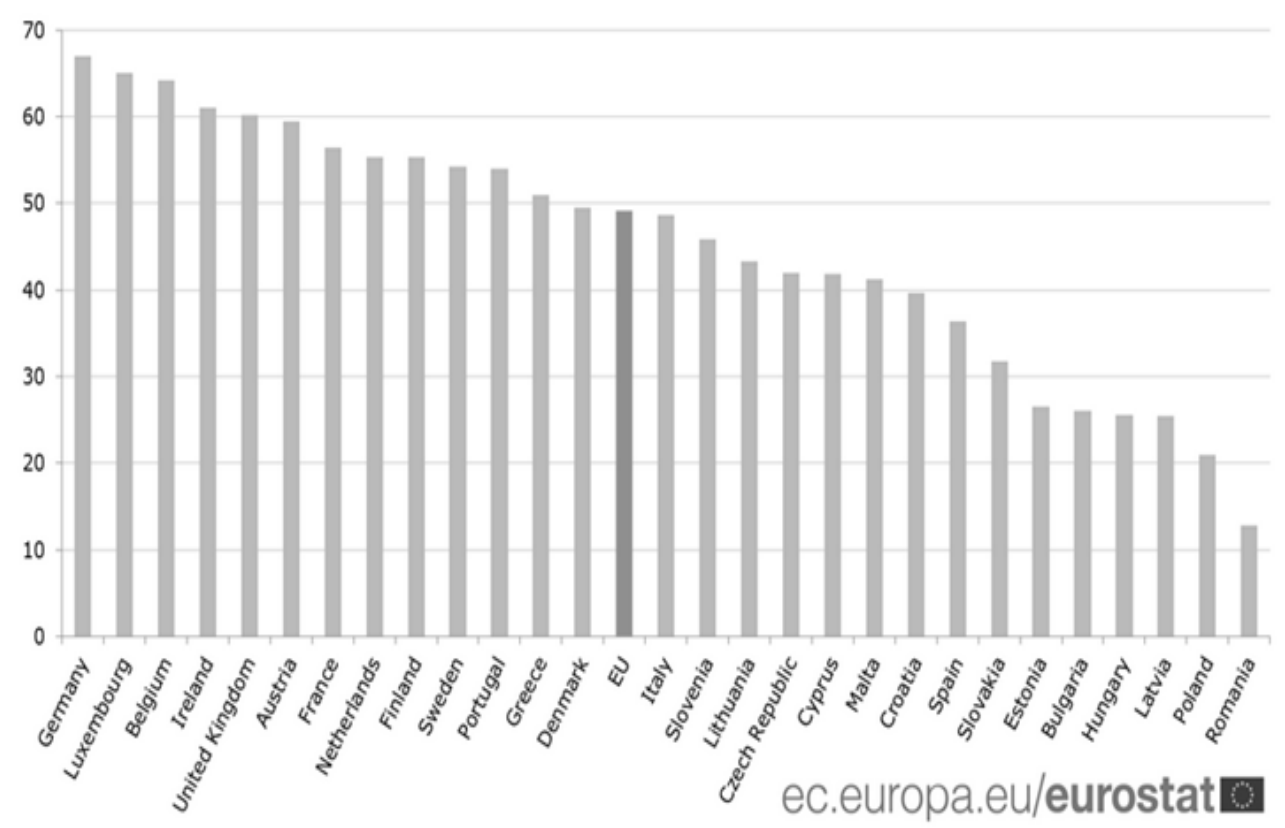

Fig.1. Level of innovation of enterprises in the EU.

\section{Source: Eurostat 2016}

Capital investments are an indicator of the financial capabilities of the enterprise, which can be used to finance innovative projects. A link between innovation activity and capital investment can be expected in cases of intensive development of the enterprise, where the need to expand the facilities stems from the introduction of new production processes and products. The use of innovative lease is one of the ways to effectively solve the problems of investing in the innovative development of agribusiness.

The receivables of leasing companies under finance and operating leasing at the end of March 2018 totaled BGN 3.634 billion (3.5 per cent of GDP) compared to BGN 3.332 billion (3.4 per cent of GDP) at the end of March 2017, according to BNB data.

At the end of the first quarter of 2017 on an annual basis they increased by 9.0 percent (BGN 301.2 million), as per data revealed by the Central Bank. Financial lease receivables 
amounted to BGN 3.437 billion at the end of the first quarter of 2018, increasing by 7.2 percent (BGN 230.7 million) on an annual basis. Receivables under finance leasing contracts for trucks and vans amounted to BGN 1.146 billion at the end of March 2018, increasing by 5.1 percent (BGN 55.5 million) compared to the end of March 2017.

At the end of the first quarter of 2018, receivables under finance lease contracts for cars amounted to BGN 1.259 billion.

On an annual basis, they increased by 20.3 percent (BGN 212.1 million). Receivables from finance lease contracts for machinery, equipment and industrial equipment amounted to BGN 682.8 million, increasing on an annual basis by 3.7 per cent (BGN 24.4 million), with the highest amount of lease receivables in the Trade sectors (26\%), Transport (18\%) and Construction (18\%). In the agricultural sector, the amount of finance lease receivables is significantly lower by about $3 \%$, which shows us that economic agents benefit insignificantly from the advantages of lease transactions and, in particular, from the opportunities of innovative lease.

Innovative lease is a specific type of economic relations between economic agents regarding the object of the leasing transaction in the process of innovation activity. (Ayupov, 2002) According to sources revealed in specialized literature, leasing is defined as "an agreement with the owner of the property (leaser) to provide the other party (lessee) its use for a certain period at a certain price...". (Milanov, 1999) It creates a rental relationship, which is related to the circumstance of providing the function of managing an innovative asset for a certain period of time, in exchange for a certain price paid. This fact is a clear confirmation of the principle that the income from an asset is obtained during its operation, and not from the advantage of owning it.

Apart from being a specific type of relationship, innovative lease can also be considered as:

- independent type of innovation activity. For certain business entities, lease commercial transactions can express their main scope of business activity and make up their source of main income. In fact, these are specialized business entities that form their own fleet of innovative products or receive them from their owners and provide them to third parties for management. Therefore, these entities carry out lease commercial transactions in terms of their principal occupation and develop their functions between the producers or owners of machinery and equipment and the economic entities consuming their efficiency.

- form of investment. In which case temporarily free or attracted funds from the lessor are invested in innovative products, under the terms of lease relations between the economic agents of the leasing transaction. One party provides assets for use and management for a certain period and the other one, uses the innovative products according to their purpose and pays certain installments determined under the lease agreement.

- form of placement. At certain times, in order to expand market share, increase revenue, lease is used by companies to market new products, i.e. it can be considered as a marketing tool for market penetration and conquring markets.

\section{Advantages and disadvantages of lease transactions}

In order to justify the economic benefits of using innovative leases, we should trace the advantages and disadvantages of leasing transactions from the prospective of all participants. (Mihailov, 2003, p. 348) For example, the benefits for the lessee are realized in several aspects: lease is an alternative for acquiring innovative assets, and to finalize the investment project the lessee does not have to provide $100 \%$ funds for the investment; in the case of lease, the issues with the acquisition and financing of the investment are resolved simultaneously; maintaining a good level of liquidity - the costs of acquiring innovative equipment are evenly distributed throughout the period. (Dobreva D. i., 2005). On the other hand, the introduction of direct payments is a mechanism for consistent market-oriented reforms that improve the competitiveness of the agricultural sector by encouraging farmers to adapt to market conditions. (Veselinova, N., 2014, p. 105) In this manner, own funds can be used for other purposes; the leasing installments are paid 
during the leasing period from the revenues as a result of the operation of the lease property; in fact, lease payments are made on a schedule that allows the lessee to coordinate its costs and revenues; leasing is a means of overcoming the obsolescence of the leased property and a means of studying the technical and economic indicators of a given equipment for the purpose of subsequent purchase; in case of low profitability, the lessee has the opportunity to lease the property / subleasing, repayable leasing /; the lessee accrues depreciation on the leased property, thus reducing its taxable base; the leased property can serve as collateral; Leasing is an opportunity to attract foreign investment by borrowing assets from foreign counterparties. (Karakasheva LL, 2001, p. 166).

The advantages for the lessor derived from leasing transactions are: leasing is a type of business activity, providing good profit by providing innovative assets under leasing; the main role in the preparation and conduct of the leasing transaction lies with the lessor. He receives additional remuneration for this service; the lessor has the opportunity to control the financial resources with which the leased property must be acquired; in case a bank or other financial institution participates in the leasing operation as a lessor, it has the opportunity to temporarily invest its free funds and thus to achieve a higher degree of liquidity in its loan portfolio. (Naidenov, Leasing - Financial and Legal Aspect, 1995, p. 40)

The economic benefits of leasing for the leasing equipment supplier are: leasing can be considered as a means of selling a new product or service; it is a marketing tool for market penetration and conquering marketing strategies; through this transaction the seller transfers all risks associated with the lessor's asset. (Pavlova, 1998, p. 7)

The disadvantage is that it is not necessary for economic agents in the agricultural sector, who do not have sufficient financial resources to purchase innovative assets, to own their own property to work and generate income and generate profit. Statistics already show a trend of accelerated high-tech implementation in some farms, which immobilizes capital and reduces their profitability. The mechanisms of innovation leasing allow them to obtain the right to use the necessary innovative products for production for a certain period, under a certain payment condition and under certain terms and conditions. Increasing competition between leasing companies forces them to look for ways to reduce the value of leasing services, which is a prerequisite for the use of various financial instruments in leasing transactions. As a result, securitization of lease receivables and synthetic leasing occur.

Based on the above, the following main conclusions can be summarized:

First. Leasing is a modern form of trade loan, which is rapidly penetrating the Bulgarian business practice in agribusiness. This is explained by the advantages it provides for the individual participants in the leasing transaction.

Second. Among the wide variety of leasing options, financial lease is of the greatest importance and applicability. It is applied as an analogue of the bank loan for servicing the investment process, which is characterized by such characteristics as longevity, return and interest rate.

Third. Financial lease, as a way of serving business interests, also involves determining its benefits for each of the parties. For the lessor it is necessary the correct calculation of the amount of the leasing installments and the efficiency of the leasing transactions to be performed, for the lessee - on the basis of the calculations a decision should be made for whether decide to proceed with a leasing or a loan.

The development of the agricultural sector also raises the need for progressively increasing and diverse forms of financing with a longer loan repayment period. For small and medium-sized agricultural holdings, the opportunities for obtaining funds are more limited. One of the possibilities is for them to use leasing as a form of commercial loan through which to obtain the necessary equipment. Financial lease provides the equipment supplier with an efficient and low-risk form of distribution. By offering leasing services in addition to its main product, it helps to attract new customers. For lessees, leasing is a cost-effective and efficient tool that allows leased equipment to 
be repaid during operation. This property brings profit from the business that is developed by means of the later. When faced with the lease or purchase dilemma, the lessee must determine the present value of the leased cash flow and compare it with the updated cost of purchasing the equipment in question. For the lessor, leasing is a business activity in which he invests funds and expects a higher return compared to similar investments.

\section{References}

1. http://enterprise-europe-network.bg/2880/indeks-na-inovatsionnata-aktivnost-na-balgarskitepredpriyatiya/. (n.d.).

2. https: //www.capital.bg/biznes/kompanii/2016/12/07/2878703_koi_sa_inovativnite_predpriiatiia _na_2016_g/. (n.d.).

3. https: //ec.europa.eu/eurostat/web/microdata/community-innovation-survey. (n.d.).

4. Adamov, V. et al., Investment decisions and investment risk in the company, Svishtov 1995

5. Adamov, V. Zahariev, V., Prodanov, S., Budget management of the company, V. Tarnovo, Abagar 2003

6. Ayupov, A. (2002). Innovative leasing in the banking sector. ,. Kazan: TISBY.

7. Veselinova, N. (2014). Opportunities and prospects for investment projects in the agricultural sector. Jubilee scientific-practical conference: THE NATIONAL AGRICULTURAL SECTOR AN ELEMENT OF THE EUROPEAN AGRICULTURAL REGIONS IN THE EUROPE 2020 STRATEGY, AI "Tsenov", Volume 2.

8. Dobreva, D. and. (2005). Trade crediting. Svishtov: AI "Tsenov".

9. Karakasheva, LL (2001). International Business. Sofia: Prism.

10. Milanov, S. (1999, 05 5). Leasing in the world economy. I k o n o $\mathrm{m}$ i c h e s k i life.

11. Mikhailov, EM (2003). Banking services for economic agents. V. Tarnovo: Abagar.

12. Naidenov, B. (1995). Leasing - financial and legal aspect. Sofia: Ciela.

13. Pavlova, M. (1998). Leasing - economic and financial accounting problems. V. Tarnovo.

14. Prodanov, S. Capital Budgeting, Veliko Tarnovo, Abagar 1999 